\title{
Urpo Harva
}

\section{Ihmiskäsitys, ihmiskatsomus ja kasvatus}

\begin{abstract}
Harva, Urpo. 1982. Ihmiskäsitys, ihmiskats॰mus ja kasvatus. Aikuiskasvatus 2, 1, 4-7. - Artikkelissa käsitellään aikuiskoulutuksen kehittämisorganisaation omaksumaa peruskäsitettä, ihmiskuva, ja sen rinnakkaiskäsitteitä. Kirjoittaja pohtii aikuiskasvatuksen perustehtäviä ja yhteiskunnallista merkitystä sekä johtaa näistä perusteita toiminnalle. Artikkelissa kritisoidaan taloudelliseen kasvuideologiaan perustuvaa yhteiskunnallisen kehityksen mallia.
\end{abstract}

\section{Käsitteistä}

Ehdotan, että 'ihmiskäsitystä' ja 'ihmiskuvaa' käytettäisiin synonyymisesti niin, että ne vastaavat kysymykseen, millainen ihminen on (vrt. maailmankäsitys, maailmankuva, saks. Weltauffassung, Weltbild). Uudeksi sanaksi ehdotan ihmiskatsomusta (vrt. maailmankatsomus. Weltanschauung), joka vastaa kysymykseen, minkälainen ihmisen pitää olla. Se on normatiivinen, aksiologinen käsite, se ilmaisee ihmisihanteen, ihmisen ideaalin, ja täten myös kasvatuksen (yhden) päämäärän.

Teoreettisesti katsoen voi olla olemassa vain yksi ainoa oikea, todellisuutta vastaava ihmiskäsitys. Se voi olla empiiris-tieteellinen tai metafyysis-uskonnollinen. Käytännössä ei ole edes yhtä ainoata tieteellistä ihmiskäsitystä, koska esim. eri psykologisten suuntien ihmiskäsitykset eroavat toisistaan.

Minulla on sellainen ihmiskäsitys, että kaikilla ihmisillä ei voi olla samanlaista ihmiskatsomusta. Ihmiskatsomus rakentuu osittain ihmiskäsityksen pohjalle, ja ihmiskäsityksethän voivat olla erilaisia. Lisäksi ihmiskatsomukseen kuuluu joitakin ihmiskäsityksen ylittäviä aineksia, vaikkapa se moraalinormi, ettei saa tehdä pahalle vastarintaa.

Ihmiskatsomukset eivät voi olla tosia ja epätosia paitsi siltä osalta, joka koskee ihmiskäsitystä. Vakaumukseni mukaan ihmiskatsomus ei saa pohjautua väärään ihmiskäsitykseen ja siksi tulee jatkuvasti koetella sen paikkansapitävyyttä (rationaalisuuden periaate).

\section{Kasvatuksen ihmiskäsitys ja-katsomus}

Aikuiskasvatuksen suunnittelussa etsitään nyt "'ihmiskuvaa"' (sana yksikössä), joka luo "yhtenäisen lähtökohdan" kehittämisorganisaation työlle. Onko tarkoitus, että perustaksi otetaan vain yksi ihmiskuva tai -katsomus?

Kysymys ei ole aiheeton. Meitä lähellä on sekä ajallisesti että paikallisesti totalitaarisia kasvatusjärjestelmiä, jotka hyväksyvät vain yhden ihmiskäsityksen ja -katsomuksen. Myös suomalaisessa kasvatusjärjestelmässä on jo selvästi havaittavissa totalitaarisia pyrkimyksiä ja piirteitä. Meillä ei ole enää yhtään yksityistä yliopistoa. Kaikkien yliopistojen hallinto ja tutkintojärjestelmä halutaan yhdenmukaistaa. Yksityiskoulut on käytännöllisesti katsoen tapettu. Hallinnollisesti niitä vielä on, mutta pedagogisesti niiden pitää olla miltei tarkkaan valtion koulujen kaltaisia. Tämä merkitsee esim., ettei kristillistä ihmiskatsomusta tunnusteta niin arvokkaaksi, että sen varaan saisi perustaa kouluja. Väitetään, että tendenssinä on ylhäältä päin suunnitella ja ohjata jo vapaata sivistystyötäkin - mikä paradoksi!

Kasvatusjärjestelmän yhdenmukaistaminen edellyttää yhden ihmiskäsityksen tai -katsomuksen omaksumista. Sellaista ei vielä ole lyöty kiinni, siksi kai sitä nyt etsitään.

Mikä tässä on kaiken takana? Yksi syy on varmaan byrokratia, jonka olemukseen kuuluu yhdenmukaistaminen, koska se tekee hallinnon helpommaksi. Syvempänä syynä on eh- 
kä poliitikkojen pyrkimys kansan yhdistämiseen; siksi puolueet ovat lähestyneet toisiaan. Tähän taas saattaa vaikuttaa $\mathrm{mm}$. halu pitää koko kansa samalla ulkopoliittisella linjalla. Minkälainen kuva tahdotaan kasvatuksen keinoin juurruuttaa jokaiseen, on vaikea nähdä. Se kai on kuitenkin selvää, että korostetusti tulee esiin homo technicus. Kapitalistit ja kommunistit, työnantajat ja työntekijät ovat yhtä mieltä siitä, että taloudellisen kasvun pitää loppumattomasti jatkua ja että täystyöllisyys on toteutettava (pientä työvoimareserviä lukuunottamatta, lisäävät kapitalistit). Työttömyyden hävittämisellä tarkoitetaan varsinaisesti vain uusien työpaikkojen luomista tuotantoon, ei henkisen kulttuurin aloille. Ei esim. yliopistoihin perusteta uusia virkoja työttömyyden torjumiseksi.

Sanomastani käy jo ilmi, etten hyväksy menossa olevaa kehitystä ja sen pohjana olevaa ajatusta, että on vain yksi ihmiskäsitys ja -katsomus (tai että muita ei saa ottaa kasvatuksen pohjaksi).

\section{Humanistinen \\ ihmiskatsomus}

Jos ainoaksi ihmiskatsomukseksi asetetaan humanistinen ihmiskäsitys, tavallaan hyväksyn sen, koska tämä on liberaalinen katsomus, joka ei kiellä olemassaolon oikeutusta muilta katsomuksilta. Nämä saattavat olla sellaisia, ettei synny ristiriitaa humanismin kanssa (esim. tietynlainen kristillinen ihmiskatsomus). Vaikka ristiriitaa olisikin (esim. tietynlainen marxilainen ihmiskatsomus), humanisti taistelee niitä vastaan aseena se ainoa ase, jonka humanisti Erasmus Rotterdamilaisen mukaan voi hyväksyä, nimittäin sermo, puhe, ei esim. tukahduttavat kasvatuspoliittiset toimenpiteet.

Mutkattominta on kuitenkin sanoa, että aikuiskasvatuksen suunnittelun pitää lähteä niiden ihmiskatsomusten tunnustamisesta, jotka aikuiskasvatuksessamme ovat olemassa (kristillinen, marxilainen, humanistinen, työväenluokan, maanviljelijäväestön). Valtiovallan ei pidä panna niitä mihinkään arvojärjestykseen. Tämä on ollut aikuiskasvatuspolitiikkamme periaatteena ja siksi sen voidaan sanoa rakentuneen humanistiselle ihmiskatsomukselle. Tällä pohjalla humanistis-demokraattisella kulttuuripluralismin pohjalla, tulisi edelleenkin seistä ja luopua totalitaarisista pyrkimyksistä, ja yhden ihmiskatsomuksen etsinnästä.

Vaikka aikuiskasvatuspolitiikan pitää mielestäni rakentua humanismin pohjalle mainit- semassani merkityksessä, se ei saa tarkoittaa sitä, että valtio suosisi erityisesti esim. humanistisia kansanopistoja muita vastaan. Meidän humanistien pitää taistella aikuiskasvatuksessa havaitsemiamme epähumanistisia piirteitä vastaan tukeutumatta valtioon, siis vain aatteellisella tasolla. Meidän on harjoitettava myös itsetutkistelua, jotta oma ihmiskatsomuksemme olisi todella humanistinen.

Kantani merkitsee, että vapaalla sivistystyöllä pitää olla laaja autonomia niin että voidaan vapaasti valita erilaisia ihmiskatsomuksia. Sitä ei saa integroida yhteiskuntapolitiikan osaksi.

Aikuiskasvatus-lehti kysyi: "'Onko ihmiskuva tarkoituksenmukainen perusta yhteiskunnalliselle suunnittelulle ja aikuiskasvatuksen kehittämiselle?' Vastaus riippuu toisaalta ihmiskuvasta, toisaalta yhteiskuntasuunnittelusta. Jos tavoitteeksi asetetaan esim. nopean taloudellisen kasvun yhteiskunta, humanistinen ihmiskatsomus tuskin sopii sen perustaksi. Valtiolla ja talouselämällä on tietenkin oikeus panna toimeen kasvuun tähtäävää koulutusta ja omaksua sen perustaksi materialistinen ihmiskatsomus, jossa materiaaliset arvot ovat ylinnä. Tällaista koulutusta voidaan harjoittaa myös vapaan sivistystyön puitteissa, mutta tällöin vaanii vaara, että humanistinen ihmiskäsitys hämärtyy.

Aikuiskasvatuksen perustaksi humanistinen ihmiskatsomus saattaa riittää, jos se piirretään niin avaraksi, että siinä otetaan huomioon itsensä kehittämisen lisäksi myös ihmisen tehtävät kansansa ja ihmiskunnan jäsenenä.

\section{Ihmiskatsomuksen kriisi}

Onko nyt erityisiä syitä pohtia ihmiskatsomusta? Eivätkö esim. kristilliset kansanopistot tiedä, minkälainen pitäisi olla sen kristillisen ihmiskäsityksen, jolle ne työnsä rakentavat? Tai onko työväenliikkeen sivistystyö ymmällä ihmiskatsomusta koskevassa kysymyksessä? Vai onko ihmiskatsomus tullut puheenaiheeksi vain siksi, että pelätään valtion taholta tyrkytettävän yhtä ihmiskatsomusta?

Oli miten oli, aikuiskasvatuksen tulee ottaa huomioon myös yhteiskunnassa vallitsevat ihmiskatsomukset. Kun ihminen tulee opintokerhon kokoukseen, hän tuo tuliaisiksi jonkin ihmiskuvan, ja kun hän taas palaa kotiinsa ja yhteiskuntaan, hän joutuu kohtaamaan joitakin ihmiskatsomuksia.

Yhteiskunnassamme onkin kriisitilaan joutuneita ihmiskatsomuksia, ennen kaikkea se katsomus, että ihmisen on oltava yhä enem- 
män tuottava ja kuluttava olento. Puhutaan myös keski-ikäisen miehen kriisistä ja uuden naiskuvan rakentamisesta. Vanhat ihmiset ovat joutuneet kysymään, mikä on heidän asemansa, merkityksensä ja tehtävänsä tuotantokoneistosta ja työelämästä jo poistuneina. Yksi yhteinen syy näihin kriiseihin on yhteiskunnan teollistuminen.

Yhteiskunnan muuttuminen siis saattaa vaatia ihmiskatsomuksien uudistamista, mikä voi olla hyvinkin kipeä prosessi.

Olemme kai yksimielisiä siitä, että aikuiskasvatuksen tulisi auttaa ihmisiä kun heidän ihmiskatsomuksensa on joutunut kriisiin. En pohdi tässä sitä varmaan vaikeata kysymystä, miten tämä voisi tapahtua. Edellytyksenä ilmeisesti on, että aikuiskasvattajat ovat selvillä ihmiskatsomuksen problematiikasta.

\section{Andragoginen antropologia}

Filosofinen antropologia on yleinen oppi ihmisestä. Pedagoginen antropologia tarkastelee ihmistä kasvatuksen näkökulmasta, ja andragoginen antropologia on siitä se osa, joka käsittelee aikuista.

Filosofisesta ja pedagogisesta antropologiasta on suunnattomasti tietoa yli kahden vuosituhannen varrelta ja sitä rupeaa olemaan aika paljon myös andragogisen antropologian alalta. En näe siinä sellaisia "valkoisia läiskiä", jotka olennaisesti haittaisivat käytännön kasvatustyötä. Tietenkin tutkimustyötä edelleen tarvitaan jo siitä syystä, että yhteiskunnan kehitys nostaa esiin uusia ongelmia. Mutta ensiluokkaisen tärkeä on kysymys, miten tiedon valtamerestä ja tiedon tulvasta saataisiin aikuiskasvattajien käyttöön juuri sellaista tietoa, jota he tarvitsevat.

Mitä tietoa siis aikuiskasvattajat tarvitsevat (subjektiivisesti ja objektiivisesti) ihmiskäsityksistä ja ihmiskatsomuksista?

En osaa tähän vastata kuin korkeintaan jotain ylimalkaista. Selvältä näyttää, että kaikki aikuiskasvattajat tarvitsevat jotakin yleistä ja yhteistä perustietoa ja että he toisaalta tarvitsevat sellaista erityistietoa, joka on relevanttia heidän erityisen asemansa ja erityisen tehtävänsä kannalta (esim. kansalaisopistojen rehtorit ja eri aineiden opettajat).

Aikuiskasvatuksen tutkijoiden pitäisi siis yhteistoiminnassa tuottaa helppolukuisia julkaisuja, jotka on tarkoitettu kaikille aikuiskasvattajille ja toisaalta erityisryhmille. Niiden pitäisi olla omakohtaiseen pohdintaan innostavia. Käsiteltävät kysymykset pitäisi valita läh- temällä toisaalta aikuiskasvattajien subjektiivisista tarpeista, toisaalta siitä, mitkä kysymykset tutkijoiden mielestä ovat objektiivisesti tärkeitä.

\section{Ajankohtaisia asioita}

Esitän seuraavassa muutamia ajankohtaisia hajamietteitä ihmiskuvasta ja -katsomuksesta.

Olen vahvasti vakuuttunut siitä, että se ihmiskatsomus, joka on kasvuideologian pohjalla, on ajautumassa umpikujaan, vaikka esim. työmarkkinajärjestöt pitävät siitä vielä kiinni kynsin hampain. Tämän katsomuksen aatehistorialliset juuret ovat toisaalta protestantismissa, toisaalta marxismissa, jotka korostavat ylenmäärin työnteon merkitystä ihmisenä olemisessa (Marxilta on kuitenkin löydettävissä myös toisenlainen aristoteelis-humanistinen ihmiskatsomus). Pidän selviönä, että ennen pitkää täytyy perusteellisesti tarkistaa kasvuideologian ihmiskatsomusta, ja näen siinä tärkeän haasteen aikuiskasvatukselle.

Tapio Vaherva ei käsittele kirjoituksissaan aikuisen uskonnollista kehitystä. Piispa Eino Sormunen mainitsi, että hän sai paljon kirjeitä, jotka kertoivat ihmisten uskonnollisesta häiriintyneisyydestä tai kehittymättömyydestä (en muista enää, mitä sanaa hän käytti). Samanlaisia kirjeitä minäkin olen saanut Aamulehden kolumnistina. Voitaisiinko tällaisten ihmisten hyväksi tehdä jotakin aikuiskasvatuksessa?

Vaherva, joka viittaa Sirkka Hirsjärven analyysiin ihmisen olemuksesta, ei juuri kiinnitä huomiota siihen, että ihminen on myös vaarannettu olento, kuten Joachim Bodamer sanoo (Der gefährdete Mensch, 1968). Ihminen on altis ei ainoastan ruumiin ja mielen sairauksille, vaan myös itsetuholle. Minusta näyttää, että Hirsjärven piirtämä kuva ihmisestä on liian valoisa. Enempää tähän kajoamatta viittaan vain Oiva Ketosen sanoihin: 'Ihminen ei tule tietoiseksi vain siitä mikä on. Hän tulee tietoiseksi myös tuntemattomasta, jonka takana on outoja mahdollisuuksia. Tietoisuuden maailma on periaatteessa tasapainoton." (Ihmisenä olemisesta, 1981). Joitakin kasvatuksellisia johtopäätöksiä kai tästäkin ihmisen olemuksen ominaisuudesta pitäisi tehdä varsinkin kun tendenssi itsetuhoon on nykyaikana suuresti vahvistunut.

Eksistenssifilosofian mukaan ihmisenä oleminen on olemista kuolemaan, Sein zum Tode (Heidegger). Todisteena ihmisen irrationaalisuudesta on, että varsinkin amerikkalainen ihminen koettaa kaikin tavoin peittää tämän osan ihmiskuvasta. 
On myös ideologioita, joiden ylläpitäjät koettavat istuttaa toisten ihmisten mieleen väärän kuvan ihmisestä.

Käsitykseni on, että aikuiskasvattajille olisi hyödyksi nähdä, minkälainen ihmiskuva ja -katsomus on ollut aikojen kuluessa aikuiskasvatuksen ja sen eri lohkojen pohjalla (A. Peltonen käsittelee koulunuudistuksen ihmiskäsitystä väitöskirjassaan 1979). Jos tällaisessa historiallisessa tutkimuksessa selvitettäisiin myös, mistä kuvat ja katsomukset ovat peräisin ja mitkä tekijät ovat niiden muuttumiseen vaikuttaneet, se antaisi oivallisia virikkeitä nykyhetken ongelmien pohtimiseen.
Yhteenvetona totean: Aikuiskasvatuksen perustana on erilaisia ihmiskäsityksiä ja -katsomuksia. Aikuiskasvatuksen tehtävänä on selventää ja syventää sen piiriin tulevien ihmiskäsitystä ja -katsomusta. Sen tehtävänä on myös kriittisesti tarkastella yhteiskunnassa vallitsevia käsityksiä ihmisestä ja auttaa tarpeen tullen niiden tarkistamisessa ja uudistamisessa. Aikuiskasvatusinstituutioilla ja aikuiskasvattajilia pitää tietenkin olla kriittinen asenne myös omiin ihmiskävityksiinsä ja -katsomuksiinsa, sillä mikään niistä ei voi ainakaan yksityiskohdissaan olla valmis ja lopullinen. 